\title{
Introduction. \\ Leave no stone unturned: Perspectives on ground stone artefact research
}

\author{
Danny Rosenberg ${ }^{1}$, Yorke Rowan ${ }^{2}$, Tatjana Gluhak ${ }^{3}$ \\ 1. Laboratory for Ground Stone Tools Research, Zinman Institute of Archaeology, University of Haifa, Haifa, \\ Israel. Email: drosenberg@research.haifa.ac.il \\ 2. Oriental Institute, University of Chicago, Chicago, USA. Email: ymrowan@uchicago.edu \\ 3. Institute for Geosciences, Team Geomaterials and Gemstone Research, Johannes Gutenberg University of \\ Mainz, Mainz, Germany. Email: gluhak@uni-mainz.de
}

\begin{abstract}
:
Ground stone tools served in many physical and social contexts through millennia, reflecting a wide variety of functions. Although ground stone tool studies were neglected for much of early archaeology, the last few decades witnessed a notable international uptick in the way archaeologists confront this multifaceted topic. Today, with the advance of archaeology as a discipline, research into ground stone artefacts is moving into a new phase that integrates high resolution documentation with new methodological, analytical techniques, and technological approaches. These open new vistas for an array of studies and wide-ranging interpretive endeavours related to understanding ground stone tool production and use. Inspired by these diverse analytical approaches and interpretive challenges, we founded the international Association for Ground Stone Tools Research (AGSTR) in order to promote dialogue and create an optimal, inclusive arena for scholars studying various aspects of ground stone artefacts. Scholars from around the globe met for a five day conference at the University of Haifa, for the first meeting of the newly founded AGSTR. This included the presentation of 47 papers and 17 posters. The current paper serves as an introduction to this special issue of JLS, devoted to the proceedings of the founding conference of the Association for Ground Stone Tool Research, held at the University of Haifa during July 2015.
\end{abstract}

Keywords: ground stone tools; food production; archaeology; anthropology; AGSTR

Ground stone artefacts served in widely divergent physical and social contexts through millennia, reflecting a variety of functions documented through a century of archaeological, ethnographic, and historical research. An ill-defined group of archaeological artefacts ranging from portable items to large immobile equipment and bedrock features, this broad artefact category cross-cuts geographic and chronological boundaries, from generalized grinding and pounding tools, to more task-specific tools, such as weapons, vessels, and single-function items. For this reason, precise definitions of "ground stone artefacts" are difficult and

Published by the School of History, Classics and Archaeology, University of Edinburgh ISSN: 2055-0472. URL: http://journals.ed.ac.uk/lithicstudies/

This work is licensed under a Creative Commons Attribution 2.5 UK: Scotland License. 
frequently pertain to a specific assemblage or group of assemblages (Gopher \& Orrelle 1995: 13; Sparks 2007: 1-3; Rosenberg \& Garfinkel 2014: XIII).

Scholars define ground stone objects in different ways, producing complex typological and classificatory systems (e.g., Warren 1969; Wright 1991, 1993; Gopher \& Orrelle 1995; Rowan 1998; Adams 2002; Beven 2007; Sparks 2007; Rosenberg \& Garfinkel 2014). These definitions typically include any item of stone which was manufactured through abrasion, polish, or pounding (impact), or a stone item used for these activities to create some other object. Such definitions rely heavily on the study of discarded finished tools (items in their 'post-production' and often 'post-use' stage) and thus the role of flaking, so central to the manufacturing of many ground stone tool types (Rosenberg et al. 2008) is commonly neglected or its importance under-valued. Moreover, while the production of ground stone tools seems to frequently involve a complex set of technologies and techniques (e.g., flaking, battering, pecking, chipping, drilling incising, abrading, polishing) and production sequences, it seems that the key qualifier for a 'ground' stone item is still, by and large, the actual raw material from which the object was made.

Unlike chipped stone tools, which are typically flint, chert or obsidian, raw material used for ground stone artefacts may be sedimentary, igneous or metamorphic rocks, depending upon factors such as local resources, availability and functional objectives. Scholars have noted the overlap between ground stone tools and chipped stone tools production, and that the categories of chipped and ground stone tools is an artificial distinction (and unrelated to geological rock classification) with greater utility to archaeologists than to the original users (Adams 2002: 1; Gebel 1999; Rowan \& Ebeling 2008: 2). This taxonomical difficulty notwithstanding, positive trends in scholarship include the adoption of more methodical approaches, systematic, analytical definitions, and greater grounding in theory and modelbased approaches. These encouraging trends are reflected in the present contributions to this issue of the Journal of Lithic Studies.

Ground stone tool studies play an increasingly integral role in holistic archaeological research programs, providing new avenues of research and interpretations. Although traditionally associated with 'prosaic' daily necessities such as food production (e.g., Rowan \& Ebeling 2008: 2-3), these important functional roles are often mistakenly treated as their sole, perhaps uninteresting, purposes. The erroneous attitude that most ground stone objects are related to food production reflects a notion that 'we understand how these objects functioned'. This lack of interest may also contain an unspoken assumption that much of this was the work of women (e.g., Rowan \& Ebeling 2008: 2). Yet ground stone tools were used to manufacture other tools and goods (e.g., Carter 2008; Harrell \& Brown 2008; Rassmann 2008; Schneider \& LaPorta 2008), they were used in ritual practice (e.g., Jones 1996; Adams 2008; Graefe et al. 2009; Larsson 2011), were associated with human burials and mortuary contexts (e.g., Ebeling 2002; Schaub 2008; Rosenberg \& Nadel 2014), and were sometimes buried themselves (Rosenberg 2013). They were often used in complex systems relating to the consolidation of communities (Wright 2000; Rosenberg 2008; Wright 2014) and reflect the division of labour (Jackson 1991; McGuire \& Hildebrandt 1994; Mobley-Tanaka 1997).

Ground stone items had an active, crucial role in a complex array of human activities that occurred in a range of contexts, from the sacred to mundane. Implied in the common assumption that ground stone tool types and assemblages are rarely sensitive indicators in chronological, cultural, or even geographical definition (i.e. that these cannot be used as reliable markers for change or differences) results in a negative feedback: by neglecting the study of ground stone objects, less comparative data was available, hindering the potential analytical value of these items.

At the regional level, ground stone tool assemblages may reflect cultural and economic changes, sometimes notably, sometimes less dramatic. Some regions witnessed a dramatic 
rise in overall tool frequencies, typological and stylistic variations, and specific raw material selection, as well as changes in contextual and discard patterns, as seen for example with the Natufian culture of the southern Levant (e.g., Wright 1991, 1994; Eitam 2008; Nadel \& Rosenberg 2010; Rosenberg et al. 2012; Valla 2012). In other cases, changes follow the introduction of new foods to a region (e.g., Morris 1990). In some cases, considerable developments are evident in the technological apparatus of tool production and the diversification of production sequences through time, reflecting notable changes in the time and energy invested in tool production.

Ground stone artefacts are used for a wealth of activities beyond grain and fruit processing. These include, for instance, the processing of herbs, minerals, meats, medicine, narcotics, preparation of alcoholic beverages, and more (e.g., Cushing 1920; Woodbury 1954; Gould et al. 1971; Gould 1977; Kraybill 1977; Hayden 1987). Ground stone tools are also involved in the manufacture of a large array of tools made of various materials such as wood, bone, rock and metal (see papers in this issue and refs. therein). Ground stone tools are used in the preparation and plastering of floors and walls, or to store materials and items, or might be used in the presentation and serving of food for daily meals and in special occasions. Ground stone tools sometimes played less well known, yet notable roles, such as textile production, or for hunting, trapping and fishing gear. Some were used in combat, such as the mace heads and sling stones. Albeit more elusive to detect archaeologically, many items embodied symbolic meanings, served as markers of identity, and were imbued with religious or ideological significance.

The significance of ground stone tools cannot be overestimated. Our earliest evidence for hominid tools are worn and damaged unworked stones, perhaps used as pitted anvils and pounding implements (e.g., Leakey 1994; de Beaune 2004 and see references therein). Evidence for the use of expedient, typically unshaped rocks by primates are also known and in the southern Levant early hominid use of stone objects has been reported (Goren-Inbar et al. 2002), indicating that such ad hoc tools were present for many millennia. The rarity of evidence for ground stone food processing tools in the late Lower, and Middle Palaeolithic, before the growing evidence for grinding in the Upper Palaeolithic sites is of note. In recent years, several studies were devoted to the use of modified or unmodified stone implements as food processing tools during the Palaeolithic period, however, so far, most of the known evidence for abrading comes from Upper Palaeolithic contexts (e.g., Aranguren et al. 2007; de Beaune 2002, 2004; Fullagar and Field 1997; Liu et al. 2013; Mariotti Lippi et al. 2015; Piperno et al. 2004; Revedin et al. 2010, 2015; Spivak \& Nadel, 2016; Wright 1991: table 1). At least in Europe, such evidence comes from both Neanderthals and modern humans sites (e.g., de Beaune 2004). At least for the Levant it seems that the boost relates to ground stone tools production should be dated to the later parts of the Epipaleolithic period (e.g., Wright 1991, 1994; Rosenberg et al. 2012). The process of neolithisation in the region, and in other regions as well, highlights the role food processing and other tools played in the transition to increasingly sedentary communities practicing full-fledged agriculture (e.g., Wright 1993). Despite their importance to this process, the common assumption that specific tool forms correlate with more mobile hunter-gatherer and sedentary groups is not demonstrated when examined carefully and with quantified data (e.g., Wright 1991).

In some instances, ground stone tools were regarded as prestige items and highly valued commodities, at least in agrarian societies (e.g., Hayden 1998), transporting and conveying significant social information within the society. The significance and social value of these tools are frequently perceived as being directly linked with social and economic processes which characterize changes in society (e.g., Searcy 2011: 3; Peacock 2013: 1-6), when specific trends and conventions developed, and increasing specialized production was noted 
alongside development of complex networks for the distribution of ground stone tools (e.g., Campbell-Smith 1965; Luke 2008; Roosevelt 2008; Rosenberg \& Golani 2012).

Despite the centrality of ground stone artefacts in so many diverse lifeways of the past, whether sedentary or mobile, prehistoric or historic, small bands, villages or cities, studies of ground stone remain in their infancy. There are various reasons for this neglect related to their size and weight, their slow pace of morphological change over time, or the curation and reuse of an object for different, secondary purposes, sometimes over a long period of time. Another reason for the de-emphasis on ground stone tool studies may stem from the inclusion of different functional types in the same analytical group, obscuring our ability to recognize meaningful diachronic trends and changes.

In the absence or near-absence of production locales (i.e. quarries, production sites, workshops) in some parts of the world (e.g., the Near East), and the common discovery of finished items in most archaeological sites, the possibility of technological analyses that relates to the earliest stages of the production are greatly reduced. Quarrying, reduction, and shaping that are frequently done at or near the quarry site where the raw material is obtained frustrates attempts to document the chaîne opératoire.

This neglect varies greatly depending on chronological periods studied, quantity of material culture, national traditions of research, and other factors, but ground stone artefacts are frequently relegated to the 'other' category of finds (Biskowski 2008: 144). In recent years, however, a change of attitude toward the study of the ground stone tools became evident, with some specific trends becoming clear. One such trend that was reflected in the papers presented during the $1^{\text {st }}$ AGSTR meeting at the University of Haifa, and visible in this JLS issue, is an increase in the number of papers dealing with ground stone quarries, production, and design (e.g., Cook 1973; Hayden 1987; Schneider 2002; Stocks 2003; Truncer 2006; Rosenberg et al. 2008; Anderson \& Scarrow 2011; Ebeling \& Rosenberg 2015; Vardi 2015; Shimelmitz \& Rosenberg 2016; Squitieri \& Eitam 2016).

Another trend gaining strength is a focus on geochemistry and provenance, distribution, and exchange (e.g., Williams-Thorpe 1988; Philip \& Williams-Thorpe 2001; Watts et al. 2004; Antonelli \& Lazzarini 2010; Tsoraki 2011; Rosenberg \& Golani 2012; Gluhak \& Rosenberg 2013; Gluhak \& Schwall 2015; Rosenberg \& Gluhak 2016; Gluhak et al. 2016; Reniere et al. 2016). Efforts to understand the functions of stone items continue through increasingly sophisticated functional use-wear analyses (e.g., Hamon 2008; Risch 2008; Verbaas \& van Gijn 2008; Delgado-Raack et al. 2009; Bofill 2012; Adams 2014; Asryan et al. 2014; Adams 2015; Delgado-Rack \& Risch 2016; Groman-Yaroslavski et al. 2016; Hamon 2016) and residue studies (e.g., Yohe II et al. 1991; Hard et al. 1996; Fullagar \& Field 1997; Veth et al. 1997; Piperno \& Holst 1998; Perry 2004; Aranguren et al. 2007; Barton 2007; Fullagar et al. 2008; Buonasera 2016; Öğüt 2016). In addition to functional and sourcing analyses, studies dealing with the role of the object in day-to-day activities, and in ritual and their symbolic dimensions, are gaining traction (e.g., Rosenberg \& Nadel 2014, Rowan 1998: 324-331; Duwe 2016; Nadel \& Rosenberg 2016).

At the same time, growth in the number of ground stone tool assemblage reports (typological and others) is noted, and suggests an increasing acceptance that description is a basic necessity of a complete archaeological report (e.g., Baysal \& Wright 2005; Rowan et al. 2006; Stroulia 2010; Rosenberg and Garfinkel 2014; Beller et al. 2016; Cohen-Klonymus \& Bar 2016; Greener \& Ben-Yosef 2016; Levy et al. 2016; Pedersen et al. 2016; Schneider et al. 2016; Spivak \& Nadel 2016). In addition, specific studies dealing with particular segments of the ground stone tool repertoire, some with specific function or functions, are becoming more common (e.g., Takaoğlu 2006; Basgall 2008; Beaumont \& Bednarik 2015; Nadel \& Rosenberg 2015; Reich 2015; Bekker \& Garfinkel 2016; Breglia et al. 2016; Ilan 2016; Larocca 2016; Larocca \& Breglia 2016; Rosenberg et al. 2016; Thiébaux et al. 2016; 
Usacheva 2016). Studies based on historical sources (see, for example, Lang 2016) and ethnographic observations (e.g., Cane 1989; Hamon \& Le Gall 2013; Robitaille 2016) are also significant and important contributions in recent years.

The compilation of information extracted from ground stone tools can be significantly advanced by combining archaeological with scientific perspectives and the application of a broad range of scientific approaches. The value of ground stone tools as containers of information that can be extracted using various micro- and macroscopic techniques, highly advance scanning and documentation methods, residue and geochemical analyses cannot be over-emphasized and may supply us with a wealth of information regarding the processing of subsistence, subsistence economies, production sites, the procurement and distribution of the raw material trading networks, and a plethora other venues.

Inspired by these diverse analytical approaches and interpretive challenges, one of the principle aims of the founding of the international Association for Ground Stone Tools Research (AGSTR) was to promote a dialogue and create an optimal arena for scholars who are interested in various issues related to ground stone artefact studies in this growing area of research. Scholars from around the globe met at the University of Haifa in July, 2015, for a five day conference for the first meeting of the newly founded AGSTR. This included the presentation of 47 papers and 17 posters.

All participants were invited to submit their papers for peer-review and inclusion in this special volume of Journal of Lithic Studies that finally includes 29 contributions. The diverse range of papers reflects the broad range of vibrant research into aspects of ground stone objects that rely on a host of different analytical techniques, some combining multiple techniques, demonstrating the vitality of this sub-field of archaeology. The success of the first AGSTR meeting and its proceedings points the way for the prospects of ground stone tools studies and the growing impact these studies are making. Now, with the founding of the new Association for Ground Stone Tool Research, the forming of AGSTR new website and Facebook, we have a suitable infrastructure to promote these venues, produce more research collaborations, promote integration of new methodologies and techniques, and advance ground stone tool studies and their interpretive potential to contribute to the wide array of research questions pertaining to the changes of human society through millennia.

\section{Acknowledgments}

Many people were part of, and made possible, the successful $1^{\text {st }}$ meeting of the newly founded Association for Ground Stone Tool Research (AGSTR) and the proceedings published in Journal of Lithic Studies. Our thanks goes especially to D. Faraggi, Rector of the University of Haifa, R. Snir, Dean of the Faculty of Humanities and A. Refter Head of Administration of the faculty, The Zinman Institute of Archaeology and its head $\mathrm{M}$. Weinstein-Evron, and its manager M. Eisenberg and to Johannes Gutenberg University and W. Hofmeister for their support and endless encouragement. We also thank the Israel National Commission for UNESCO and its secretary general D. Atrakchi, to the W.F. Albright Institute of Archaeological Research, Jerusalem and its director M. Adams, and to BETA Analytic for supporting the conference. Special thanks also go to O. Crandell, Editorin-Chief of Journal of Lithic Studies, and to O. Bar-Yosef, our keynote speaker. We also would like to thank T. Laviel for her expert help before and during the AGSTR meeting; to A. Zohar and M. Bugaev for designing the conference website, to A. Regev for her patient assistance with all graphic design matters and to I. Rosenberg for designing the AGSTR logo. We also thank Dr. Z. Tsuk and E. Hefez of the Israel Nature and Parks Authority and the many researchers of the Israel Antiquities Authority and other institutions who allowed us to examine the ground stone tools from their excavations. And last, but not least, the students of 
the Laboratory for Ground Stone Tools Research at the Zinman Institute of Archaeology, University of Haifa, M. Agnon, B. Tzin, S. Pinski, T. Shooval and S. Bar-Giora for their patient and indulgent assistance, and their contributions for the successes of the 'Ground Stone Tools and Society' conference. Special thanks go also to S. Pinsky and R. Chasan for their patience checking and formatting all contributions for this special issue of Journal of Lithic Studies and to all the reviewers who kindly agreed to review the contribution of this special issue of Journal of Lithic Studies.

\section{References}

Adams, J. L. 2002, Ground Stone Analysis: A Technological Approach. The University of Utah Press, Salt Lake City, 320 p.

Adams, J. L. 2008, Beyond the broken. In: New Approaches to Old Stones. Recent Studies of Ground Stone Artifacts (Rowan, Y. M., \& Ebeling, J. R., Eds.), Equinox, London: p. 213-229.

Adams, J. L. 2014, Ground stone use-wear analysis: A review of terminology and experimental methods. Journal of Archaeological Science, 48: 129-138. doi:10.1016/j.jas.2013.01.030

Adams, J. L. 2015, An experimental approach to answering the question - how did they do that? In: Las Capas Archaeology Project: Ground Stone and Maize Processing Experiments. Technical Report No. 2014-02 (Adams, J. L., Rychener, J. S., \& Denoyer, A. J., Eds.), Desert Archeology, Inc., Tucson, AZ: p. 1-5.

Anderson, T. J., \& Scarrow, J. H. 2011, Millstone quarries in southern Spain: preliminary pinpointing of provenance and production- exploiting the Internet. In: Bread for the People: The Archaeology of Mills and Milling. Proceedings of a colloquium held in the British School at Rome $4^{\text {th }}-7^{\text {th }}$ November 2009 (Williams, D., \& Peacock, D., Eds), Series in Archaeology Monographs Vol. 3, Archaeopress, Oxford: p. 259-275.

Antonelli, F., \& Lazzarini, L. 2010, Mediterranean trade in the most widespread Roman volcanic millstone from Italy and petrochemical markers of their raw materials. Journal of Archaeological Science, 37: 2081-2092. doi:10.1016/j.jas.2010.02.008

Aranguren, B., Becattini, R., Lippi, M. M., \& Revedin, A. 2007, Grinding flour in Upper Palaeolithic Europe (25,000 years bp). Antiquity, 81: 845-855. doi:10.1017/S0003598X00095946

Asryan, L., Ollé, A., \& Moloney, N. 2014, Reality and confusion in the recognition of postdepositional alterations and use-wear: an experimental approach on basalt tools. Journal of Lithic Studies, 1(1): 9-32. doi:10.2218/jls.v1i1.815

Barton, H. 2007, Starch residues on museum artefacts: Implications for determining tool use. Journal of Archaeological Science, 34: 1752-1762. doi:10.1016/j.jas.2007.01.007

Basgall, M. E. 2008, Variation in the organization of prehistoric milling technologies of the Northern Mojave Desert, North America. In: New Approaches to Old Stones - Recent Studies of Ground Stone Artifacts (Rowan, Y. M., \& Ebeling J. R., Eds.), Equinox, London: p. 196-212. 
Baysal, A., \& Wright, K. I. 2005, Cooking, crafts and curation: The ground stone artefacts from Çatalhöyük, 1995-1999. In: Çatalhöyük Research Project, Vol. 5. Changing Materialities at Çatalhöyük: Reports from the 1995-1999 Seasons (Hodder, I., Ed.), British Institute for Archaeology at Ankara Monograph Vol. 39, Monographs of the McDonald Institute for Archaeological Research. University of Cambridge, British Institute for Archaeology at Ankara, Cambridge and London: p. 307-324.

Beaumont, P. B., \& Bednarik, R. G. 2015, Concerning a cupule sequence on the edge of the Kalahari Desert in South Africa. Rock Art Research, 32(2): 163-177.

de Beaune, S. A, 2002. Origine du materiel de broyage au Paléolithique. In: Modure et Broyer II - Archéologie et Histoire (Procopiou, H. \& Treuil, R.,Eds.), Le Comité des Travaux Historiques et Scientifiques, Paris: p. 27-44.

de Beaune, S. A. 2004, The invention of technology-prehistory and cognition. Current Anthropology, 45(2): 139-162. doi:10.1086/381045

Bekker, M., \& Garfinkel, Y. 2016, Stone pedestalled vessels from Tel Tsaf, a Middle Chalcolithic site in the Central Jordan Valley, Israel. Journal of Lithic Studies, 3(3): 1729 p. doi:10.2218/jls.v3i3.1654

Beller, J. A., Greenfield, H. J., Shai, I., \& Maeir, A. M. 2016, The life-history of basalt ground stone artefacts from early urban domestic contexts: A chronicle from the EB III of Tell es-Safi/Gath, Israel. Journal of Lithic Studies, 3(3): 31-555 p. doi:10.2218/jls.v3i3.1675

Beven, A. 2007, Stone Vessels and Values in the Bronze Age Mediterranean. University College London, Institute of Archaeology, Cambridge University Press, Cambridge, $310 \mathrm{p}$.

Biskowski, M. 2008, Maize-grinding tools in prehispanic central Mexico. In: New Approaches to Old Stones - Recent Studies of Ground Stone Artifacts (Rowan, Y. M., \& Ebeling, J. R., Eds.), Equinox, London: p. 144-159.

Bofill, M. 2012, Quantitative analysis of use-wear patterns: A functional approach to the study of grinding stones. Broadening Horizons, 3: 57-78.

Breglia, F., Caricola, I., \& Larocca, F. 2016, Macrolithic tools for mining and primary processing of metal ores from the site of Grotta della Monaca (Calabria, Italy). Journal of Lithic Studies, 3(3): 57-76 p. doi:10.2218/jls.v3i3.1651

Buonasera, T. 2016, Lipid residues preserved in sheltered bedrock features at Gila Cliff dwellings National Monument, New Mexico. Journal of Lithic Studies, 3(3): 78-101 p. doi:10.2218/jls.v3i3.1304

Campbell-Smith, W. 1965, The distribution of jade axes in Europe. Proceedings of the Prehistoric Society, 31: 25-33. doi:10.1017/S0079497X00014699

Cane, S. 1989, Australian aboriginal seed grinding and its archaeological record: A case study from the Western Desert. In: Foraging \& Farming. The Evolution of Plant Exploitation (Harris, D. R. \& Hillman, G. C., Eds.), One World Archaeology Vol. 13, Unwin Hyman, London: p. 99-119.

Carter, T. 2008, Beyond the Mohs scale: Raw material choice and the production of stone vases in a Late Minoan context. In: New Approaches to Old Stones - Recent Studies of Ground Stone Artifacts (Rowan, Y. M., \& Ebeling J. R., Eds.), Equinox, London: p. 6681. 
Cohen Klonymus, H., \& Bar, S. 2016, Ground stone tool assemblages at the end of the Chalcolithic period - A preliminary analysis of the Late Chalcolithic sites in the Fazael Valley. Journal of Lithic Studies, 3(3): 103-123 p. doi:10.2218/jls.v3i3.1676

Cook, S. 1973, Stone tools for steel-age Mexicans? Aspects of production in a Zapotec stoneworking industry. American Anthropologist, 75: 1485-1503. doi:10.1525/aa.1973.75.5.02a00180

Cushing, F.H. 1920, Zuni Breadstuff. Heye Foundation Museum of the American Indian, New York, $712 \mathrm{p}$.

Delgado-Raack, S., Gómez-Gras, D., \& Risch, R. 2009, The mechanical properties of macrolithic artifacts: A methodological background for functional analysis. Journal of Archaeological Science, 36: 1823-1831. doi:10.1016/j.jas.2009.03.033

Delgado-Raack, S., \& Risch, R. 2016, Bronze Age cereal processing in southern Iberia: A material approach to the production and use of grinding equipment. Journal of Lithic Studies, 3(3): 125-145 p. doi:10.2218/jls.v3i3.1650

Duwe, S. 2016, Cupules and the creation of the Tewa world. Journal of Lithic Studies, 3(3): 147-168 p. doi:10.2218/jls.v3i3.1500

Ebeling, J. R. 2002, Why are ground stone tools found in Middle and Late Bronze Age burials? Near Eastern Archaeology, 65(2): 149-151.

Ebeling, J. R., \& Rosenberg, D. 2015, A basalt vessel workshop and its products at Iron Age Hazor, Israel. Journal of Field Archaeology, 40(6): 665-674. doi:10.1080/00934690.2015.1101941

Eitam, D. 2008, Plant food in the Late Natufian: The oblong conical mortar as a case study. Journal of the Israel Prehistoric Society, 38: 133-151. URL: http://www.jstor.org/stable/23386442

Fullagar, R., \& Field, J. 1997, Pleistocene seed-grinding implements from the Australian arid zone. Antiquity, 71: 300-307. doi:10.1017/S0003598X00084921

Fullagar, R., Field, J., \& Kealhofer, L. 2008, Grinding stones and seeds of change starch and phytoliths as evidence of plant food processing. In: New Approaches to Old Stones Recent Studies of Ground Stone Artifacts (Rowan, Y. M., \& Ebeling J. R., Eds.), Equinox, London: p. 159-172.

Gebel, H. G. K. 1999, Flint "bowlets” from the LPPNB of Southern Jordan. Neo-Lithics, 2(99): 12-13. URL: http://www.exoriente.org/docs/00030.pdf

Gluhak, T. M., \& Rosenberg, D. 2013, Geochemical discrimination of basaltic sources as a tool for provenance analyses of bifacial tools in the southern Levant: First results from the Jezreel Valley, Israel. Journal of Archaeological Science, 40: 1611-1622. doi:10.1016/j.jas.2012.11.003

Gluhak, T. M., Rosenberg, D., \& Ebeling, J. R. 2016, Raw material variability as archaeological tools: Preliminary results from a geochemical study of the basalt vessel workshop at Iron Age Tel Hazor, Israel. Journal of Lithic Studies, 3(3): 169-189 p. doi:10.2218/jls.v3i3.1677

Gluhak, T. M., \& Schwall, C. 2015, Provenance analyses of the volcanic rock grinding stones from the Greek Colony of Selinunte, Sicily (Italy) - constraints and possibilities. Archaeometry, 57(2): 246-268. doi:10.1111/arcm.12086 
Gopher, A., \& Orrelle, E. 1995, The Ground Stone Assemblages of Munhata. Les Cahiers des Missions Archéologiques Françaises en Israël Vol. 7, Association Paléorient, Paris, $184 \mathrm{p}$.

Goren-Inbar, N., Sharon, Y., Melamed, Y., \& Kislev, M. 2002, Nuts, nut cracking, and pitted stones at Gesher Benot Ya'aqov, Israel. Proceedings of the National Academy of Sciences, 99(4): 2455-2460. doi:10.1073/pnas.032570499

Gould, R. A. 1977, Ethnoarchaeology; or, Where do models come from? In: Stone Tools as Cultural Markers (Wright, R. V. S., Ed.), Prehistory and Material Culture Series Vol. 12, Humanities Press, New Jersey: p. 162-168.

Gould, R. A., Koster, D. A., \& Sontz, A. H. L. 1971, The lithic assemblage of the Western Desert aborigines of Australia. American Antiquity, 36(2): 149-169.

URL: http://www.jstor.org/stable/278668

Graefe, J., Hamon, C., Lidström-Holmberg, C., Tsoraki, C., \& Watts, S. 2009, Subsistence, social and ritual practices: Quern deposits in the Neolithic societies of Europe. In: Réalités archéologiques et histiriques des «Dépôts» de la Préhistoire à nos jours (Bonnardin, S., Hamon, C., Lauwers, M., \& Quilliec, B., Eds.), XXIX ${ }^{\mathrm{e}}$ Rencontres Internationals d'Archéologie et d'Histoire d'Antibes, Éditions APDCA (Association pour la Promotion et la Diffusion des Connaissances Archéologiques), Antibes: p. 87-96.

Greener, A., \& Ben-Yosef, E. 2016, The ground stone assemblage of a metal workers community: An unexplored dimension of Iron Age copper production at Timna. Journal of Lithic Studies, 3(3): 191-120 p. doi:10.2218/jls.v3i3.1678

Groman-Yaroslavski, I., Rosenberg’ D., Yeshurun, R., Kaufman, D., \& Weinstein-Evron, M. 2016, The function of Early Natufian Grooved Basalt artifacts from el-Wad Terrace, Mount Carmel, Israel: Preliminary results of a use-wear analysis. Journal of Lithic Studies, 3(3): 221-242 p. doi:10.2218/jls.v3i3.1508

Hamon, C. 2008, Functional analysis of stone grinding and polishing tools from the earliest Neolithic of North-Western Europe. Journal of Archaeological Science, 35: 1502-1520. doi:10.1016/j.jas.2007.10.017

Hamon, C. 2016, Technology and function of grooved abraders in the early Neolithic of north-western Europe. Journal of Lithic Studies, 3(3): 243-259 p. doi:10.2218/jls.v3i3.1649

Hamon, C., \& Le Gall, V. 2013, Millet and sauce: The uses and functions of querns among the Minyanka (Mali). Journal of Anthropological Archaeology, 32(1): 109-121. doi:10.1016/j.jaa.2012.12.002

Hard, R. J., Mauldin, R. P., \& Raymond, G. R. 1996, Mano size, stable carbon isotope ratios, and macrobotanical remains as multiple lines of evidence of maize dependence in the American Southwest. Journal of Archaeological Method and Theory, 3(4): 253-318. doi:10.1007/BF02229401

Harrell, J. A., \& Brown, V. M. 2008, Discovery of a Medieval Islamic industry for Steatite cooking vessels in Egypt's Eastern Desert. In: New Approaches to Old Stones - Recent Studies of Ground Stone Artifacts (Rowan, Y. M., \& Ebeling J. R., Eds.), Equinox, London: p. 41-65.

Hayden, B., 1987. Past to present uses of stone tools in the Mayan Highlands. In: Lithic Studies Among the Contemporary Highland Maya (Hayden, B., Ed.), University of Arizona Press, Tucson: p. 160-234. 
Hayden, B. 1998, Practical and prestige technologies: The evolution of material systems. Journal of Archaeological Method and Theory, 5(1): 1-55. doi:10.1007/BF02428415

Ilan, D. 2016, The ground stone components of drills in the ancient Near East: Sockets, flywheels, cobble Weights, and drill bits. Journal of Lithic Studies, 3(3): 261-277 p. doi:10.2218/jls.v3i3.1642

Jackson, T. L. 1991, Pounding a corn: Women's production as social and economic focus. In: Engendering Archaeology (Gero, J. M., \& Conkey, M. W., Eds.), Social Anthropology, Basil Blackwell, London: p. 301-325.

Jones, T. L. 1996, Mortars, pestles, and division of labor in prehistoric California: A view from Big Sur. American Antiquity, 61(2): 243-264. doi:10.2307/282420

Kraybill, N. 1977, Pre-agricultural tools for the preparation of foods in the Old World. In: Origins of Agriculture (Reed, C. A., Ed.), Mouton, Paris: p. 485-521.

Lang, E. 2016, “Maids at the Grindstone”: A comparative study of New Kingdom Egypt grain grinders. Journal of Lithic Studies, 3(3): 279-289 p. doi:10.2218/jls.v3i3.1462

Larocca, F. 2016, Ground stone percussion tools from Maltese Islands. Journal of Lithic Studies, 3(3): 291-300 p. doi:10.2218/jls.v3i3.1674

Larocca, F., \& Breglia, F. 2016, Grooved stone tools from Calabria region (Italy). Archaeological evidences and research perspectives. Journal of Lithic Studies, 3(3): 301-312 p. doi:10.2218/jls.v3i3.1673

Larsson, L. 2011, The ritual use of axes. In: Stone Axe Studies III (Davis, V., \& Edmond, M., Eds.), Oxbow Books, Oxford: p. 203-214.

Leakey, M.D. 1994, Introduction. In: Olduvai Gorge, Vol. 5, Excavations in Beds III and IV and the Masek Beds, 1968-1971 (Leakey, M. D., \& Roe, D. A., Eds.), Cambridge University Press, Cambridge: p. 15-129.

Levy, T. E., Bettilyon, M., \& Burton, M. M. 2016, The Iron Age copper industrial complex: A preliminary study of the role of ground stone tools at Khirbat en-Nahas, Jordan. Journal of Lithic Studies, 3(3): 313-335 p. doi:10.2218/jls.v3i3.1648

Liu, L., Bestel, S., Shi, J., Song, Y., \& Chen, X. 2013, Paleolithic human exploitation of plant foods during the last glacial maximum in North China. Proceedings of the National Academy of Sciences, 110(4): 5380-5385. doi:10.1073/pnas.1217864110

Luke, C. 2008, Carving luxury: Late Classic white stone vase traditions in Mesoamerica. In: New Approaches to Old Stones - Recent Studies of Ground Stone Artifacts (Rowan, Y. M., \& Ebeling J. R., Eds.), Equinox, London: p. 298-319.

Mariotti Lippi, M., Foggi, B., Aranguren, B., Ronchitelli, A. \& Revedin, A. 2015, Multistep food plant processing at Grotta Paglicci (Southern Italy) around 32,600 cal. BP. Proceedings of the National Academy of Sciences, 112(39): 12075-12080. doi:10.1073/pnas.1505213112

McGuire, K., \& Hildebrandt, W.R. 1994, The possibilities of woman and man: Gender and the California Milling Stone Horizon. Journal of California and Great Basin Anthropology, 16(1): 41-59. URL: http://www.jstor.org/stable/27825535

Mobley-Tanaka, J. L. 1997, Gender and ritual space during the Pithouse to Pueblo Transition: Subterranean mealing rooms in the North American Southwest. American Antiquity, 62(3): 437-448. doi:10.2307/282164 
Morris, D. H. 1990, Changes in ground stone following the introduction of maize into the American Southwest. Journal of Anthropological Research, 46(2): 177-194. URL: http://www.jstor.org/stable/3630071

Nadel, D., \& Rosenberg, D. 2010, New insights into Late Natufian bedrock features (mortars and cupmarks). Eurasian Prehistory, 7(1): 65-87.

Nadel, D., \& Rosenberg, D. 2015, (Early) bedrock features. In: Archaeology of Food - An Encyclopaedia (Bescherer Metheny, K., \& Beaudry, M. C., Eds.), Rowman \& Littlefield Publishers, Lanham, Maryland: p. 45-46.

Nadel, D., \& Rosenberg, D. 2016, A grid-like incised pattern inside a Natufian bedrock mortar, Raqefet Cave, Israel. Journal of Lithic Studies, 3(3): 337-357 p. doi:10.2218/jls.v3i3.1467

Öğüt, B. 2016, Plant use from the grinding stones' viewpoint - Phytolith analyses from Aeneolithic Monjukli Depe, Turkmenistan. Journal of Lithic Studies, 3(3): 359-377 p. doi:10.2218/jls.v3i3.1509

Peacock, D. 2013, The Stone of Life: Querns, Mills and Flour Production in Europe Up to c. $A D$ 500. Highfield Press, Southampton, 220 p.

Pedersen, P. N., Richter, T., \& Arranz-Otaegui, A. 2016, Preliminary Analysis of the Late Natufian Ground stone from Shubayqa 1, Jordan. Journal of Lithic Studies, 3(3): 379402 p. doi:10.2218/jls.v3i3.1647

Perry, L. 2004, Starch analysis reveals the relationship between tool type and function: An example from the Orinoco Valley, of Venezuela. Journal of Archaeological Science, 31: 1069-1081. doi:10.1016/j.jas.2004.01.002

Philip, G., \& Williams-Thorpe, O. 2001, The production and consumption of basalt artefact in the southern Levant during the $5^{\text {th }}-4^{\text {th }}$ millennia BC: A geochemical and petrographic investigation. Archaeological Sciences, 97: 11-30.

Piperno, D. R., \& Holst, I. 1998, The presence of starch grains on prehistoric stone tools from the humid Neotropics: Indications of early tuber use and agriculture in Panama. Journal of Archaeological Science, 25: 765-776. doi:10.1006/jasc.1997.0258

Piperno, D. R., Weiss, E., Holst, I. \& Nadel, D. 2004, Processing of wild cereal grains in the Upper Palaeolithic revealed by starch grain analysis. Nature, 430: 670-673. doi:10.1038/nature02734

Rassmann, P. M. 2008, Stones on stone: Assessing the use of handstones as tools to process stone artifacts as PPNB Baja in Southern Jordan. In: New Approaches to Old Stones Recent Studies of Ground Stone Artifacts (Rowan, Y. M., \& Ebeling J. R., Eds.), Equinox, London: p. 82-98.

Reich, R. 2015, Stone Scale-Weights of the Late Second Temple Period. Zinman Institute of Archaeology, University of Haifa, Israel Exploration Society, Jerusalem, 264 p.

Reniere, S., Dreesen, R., Fronteau, G., Gluhak, T., Goemaere, E., Hartoch, E., Picavet, P., \& De Clercq, W. 2016, Querns and mills during Roman times at the northern frontier of the Roman Empire (Belgium, Northern France, Southern Netherlands, Western Germany): Unraveling geological and geographical provenances, a multidisciplinary research project. Journal of Lithic Studies, 3(3): 403-428 p. doi:10.2218/jls.v3i3.1640 
Revedin, A., Aranguren, B., Becattini, R., Longo, L., Marconi, E., Lippi, M. M., Skakun, N., Sinitsyn, A., Spiridonova, E., \& Svoboda, J. 2010, Thirty thousand-year-old evidence of plant food processing. Proceedings of the National Academy of Sciences, 107(44): 18815-18819. doi:10.1073/pnas.1006993107

Revedin, A., Longo, L., Mariotti Lippi, M., Marconi, E., Ronchitelli, A., Svoboda, J., Anichini, E., Gennai, M., \& Aranguren, B. 2015, New technologies for plant food processing in the Gravettian. Quaternary International, 359-360: 77-88. doi:10.1016/j.quaint.2014.09.066

Risch, R. 2008, From production traces to social organization: towards an epistemology of functional analysis. In: "Prehistoric Technology" 40 Years Later: Functional Studies and the Russian Legacy (Longo, L., \& Skakun, N., Eds.), Proceedings of the International Congress, Verona, BAR International Series Vol. 1783, Archaeopress, Oxford: p. 513-521.

Robitaille, J. 2016, The ground stone industry of the Mursi of Maki, Ethiopia: Ethnoarchaeological research on milling and crushing equipment techniques and Functions. Journal of Lithic Studies, 3(3): 429-456 p. doi:10.2218/jls.v3i3.1680

Roosevelt, C. H. 2008, Stone alabastra in Western Anatolia. In: New Approaches to Old Stones - Recent Studies of Ground Stone Artifacts (Rowan, Y. M., \& Ebeling J. R., Eds.), Equinox, London: p. 285-297.

Rosenberg, D. 2008, Serving meals making a home - The PPNA limestone vessel industry of the Southern Levant and its importance to the Neolithic Revolution. Paléorient, 34(1): 23-32. doi:10.3406/paleo.2008.5231

Rosenberg, D. 2013, Not 'just another brick in the wall?' The symbolism of groundstone tools in Natufian and Early Neolithic Levantine constructions. Cambridge Archaeological Journal, 23(2): 185-201. doi:10.1017/S095977431300022X

Rosenberg, D., Agnon, M., \& Kaufman, D. 2016, Conventions in fresh water fishing in the prehistoric southern Levant: The evidence from the study of Neolithic Beisamoun notched pebbles. Journal of Lithic Studies, 3(3): 457-478 p. doi:10.2218/jls.v3i3.1639

Rosenberg, D., \& Garfinkel, Y. 2014, The Groundstone Industry of Sha 'ar Hagolan - Stone Working at the Dawn of Pottery Production in the Southern Levant. The Institute of Archaeology, the Hebrew University of Jerusalem and the Israel Exploration Fund, Jerusalem, 336 p.

Rosenberg, D., \& Gluhak, T. M. 2016, Trade me an axe? Interpretive challenges of the distribution and provenance of Neolithic basaltic bifacial tools in Israel. Antiquity, 90(349): 48-63. doi:10.15184/aqy.2015.191

Rosenberg, D., \& Golani, A. 2012.,Groundstone tools of a 'coppersmiths' community Understanding stone-related aspects of the Early Bronze Age site of Ashqelon Barnea. Journal of Mediterranean Archaeology, 25(1): 27-51. doi:10.1558/jmea.v25i1.27

Rosenberg, D., \& Nadel, D. 2014, The sounds of pounding: Boulder mortars and their significance to Natufian burial customs. Current Anthropology, 55(6): 784-812. doi:10.1086/679287

Rosenberg, D., Kaufman, D., Yeshurun, R., \& Weinstein-Evron, M. 2012, The broken record: The Natufian groundstone assemblage from el-Wad Terrace (Mount Carmel, Israel) Attributes and their interpretation. Journal of Eurasian Prehistory, 9(1-2): 93-128. 
Rosenberg, D., Shimelmitz, R., \& Nativ, A. 2008, Basalt bifacials production in the Southern Levant: A glance at the quarry and workshop site of Giveat Kipod, Israel. Antiquity, 82: 367-376. doi:10.1017/S0003598X00096861

Rowan, Y. M. 1998, Ancient Distribution and Deposition of Prestige Objects: Basalt Vessels during Late Prehistory in the Southern Levant. Unpublished Ph.D. dissertation, The University of Texas, Austin, 518 p.

Rowan, Y. M., \& Ebeling, J. R. 2008, Introduction: The potential of ground stone studies. In: New Approaches to Old Stones - Recent Studies of Ground Stone Artifacts (Rowan, Y. M., \& Ebeling J. R., Eds.), Equinox, London: p. 1-15.

Rowan, Y. M., Levy, T., Alon, D., \& Goren, Y. 2006, Gilat's ground stone assemblage: Stone fenestrated stands, bowls, platters and related artifacts. In: Archaeology, Anthropology and Cult (Levy, T., Ed.), Equinox, London: p. 575-684.

Schaub, R. T. 2008, Basalt bowls in EB IA tombs at Bab edh-Dhra': Production, placement and symbolism. In: New Approaches to Old Stones - Recent Studies of Ground Stone Artifacts (Rowan, Y. M., \& Ebeling J. R., Eds.), Equinox, London: p. 277-284.

Schneider, J. S. 2002, Milling tool design, stone textures, and function. In: Moudre et Broyer I - L'interprétation Fonctionnelle de l'Outillage de Mouture et de Broyage dans la Préhistoire et l'Antiquité - Méthodes (Vol. 1) (Procopiou, H., \& Treuil, E., Eds.), Comité des Travaux Historiques et Scientifiques, Paris: p. 31-53.

Schneider, J. S., \& LaPorta, P. C. 2008, Geological constrains on ground stone production and consumption in the Southern Levant. In: New Approaches to Old Stones - Recent Studies of Ground Stone Artifacts (Rowan, Y. M., \& Ebeling J. R., Eds.), Equinox, London: p. 19-40.

Schneider, J. S., Tserendagva, Y., Hart, T. C., Rosen, A. M., \& Spiro, A. 2016, Mongolian "Neolithic" and Early Bronze Age ground stone tools from the northern edge of the Gobi Desert. Journal of Lithic Studies, 3(3): 479-497 p. doi:10.2218/jls.v3i3.1641

Searcy, M.T. 2011, The Life-Giving Stone Ethnoarchaeology of Maya Metates. The University of Arizona Press, Tucson, 192 p. doi:10.1111/blar.12093

Shimelmitz, R., \& Rosenberg, D. 2016, The organization of basanite bifacial production in Giv'at Kipod quarry, Israel: Towards an 'Alyawara Day' model of extraction. Journal of Lithic Studies, 3(3): 499-521 p. doi:10.2218/jls.v3i3.1643

Sparks, R. T. 2007, Stone Vessels in the Levant. Palestine Exploration Fund Annual Vol. 8, Maney Publishing, Leeds, 488 p.

Spivak, P., \& Nadel, D. 2016, The use of stone at Ohalo II, a 23,000 year old site in the Jordan Valley, Israel. Journal of Lithic Studies, 3(3): 523-552 p. doi:10.2218/jls.v3i3.1646

Squitieri, A., \& Eitam, D. 2016, An experimental approach to ground stone tool manufacture. Journal of Lithic Studies, 3(3): 553-564 p. doi:10.2218/jls.v3i3.1681

Stocks, D. A. 2003, Experiments in Egyptian Archaeology Stoneworking Technology in Ancient Egypt. Routledge, New York, 296 p.

Stroulia, A. 2010, Flexible Stones: Ground Stone Tools from Franchthi Cave. Fascicle 14. Bloomington, Indiana, $242 \mathrm{p}$. 
Takaoğlu, T. 2006, Ground stone grooved hammers from Coşkuntepe. In: Kültürlerin Yansimasi / Studies in Honor of Hayat Erkanal Cultural Reflections (Avunç, B., Ed.), Homer Kitabevi, Istanbul: p. 705-707.

Thiébaux, A., Feller, M., Duchêne, B., \& Goemaere, E. 2016, Roman whetstone production in northern Gaul (Belgium and northern France). Journal of Lithic Studies, 3(3): 565-587 p. doi:10.2218/jls.v3i3.1672

Truncer, J. 2006, Taking variation seriously: The case of steatite vessel manufacture. American Antiquity, 71(1): 157-163. doi:10.2307/40035326

Tsoraki, C. 2011, Disentangling Neolithic networks. Ground stone technology, material engagements and networks of action. In: Tracing Prehistoric Social Network through Technology. A Diachronic Perspective on the Aegean (Brysbaert, A., Ed.), Routledge, New York: p. 12-29.

Usacheva, I. 2016, Transverse grooved artefacts from Southwestern Asia and Northern Eurasia: Common traits and the reconstruction of function. Journal of Lithic Studies, 3(3): 589-606 p. doi:10.2218/jls.v3i3.1653

Valla, F. R., 2012, Le matériel en pierre. In: Les Fouilles de la Terrasse d'Hayonim (Israël) 1980-1981 et 1985-1989 (Valla, F. R., Ed.), Mémoires et Travaux du Centre de Recherche Français à Jerusalem Vol. 10. De Boccard, Paris: p. 299-320.

Vardi, J. 2015, Larnite-bearing rock - The discovery of a new source of raw material in the production of Neolithic and Chalcolithic bifacial tools. Archaeometry, 57: 20-35. doi:10.1111/arcm.12131

Verbaas, A., \& van Gijn, A. 2008, Querns and other hard stone tools from GeleenJanskamperveld. In: Excavations at Geleen-Janskamperveld 1990/1991 (van de Velde, P., Ed.), Analecta Praehistorica Leidensia Vol. 39, Publication of the Faculty of Archaeology, Leiden University, Leiden: p. 191-204.

Veth, P., Fullagar, R., \& Gould, R. 1997, Residue and use-wear analysis of grinding implements from Puntutjarpa Rockshelter in the Western Desert: Current and proposed research. Australian Archaeology, 44: 23-25. doi:10.1080/03122417.1997.11681590

Warren, P. 1969, Minoan Stone Vases. Cambridge University Press, Cambridge, 280 p.

Watts, B. G., Bennet, M. E., Kopp, O. C., \& Mattingly, G. L. 2004, Geochemistry and petrography of basalt grinding stones from the Karak Plateau, Central Jordan. Geoarchaeology, 19(1): 47-69. doi:10.1002/gea.10103

Williams-Thorpe, O. 1988, Provenancing and archaeology of Roman millstones from the Mediterranean area. Journal of Archaeological Science, 15: 253-305. doi:10.1016/03054403(88)90066-0

Woodbury, R. B. 1954, Prehistoric Stone Implements of Northeastern Arizona. Papers of the Peabody Museum of American Archaeology and Ethnology, Vol. 34, Peabody Museum of American Archaeology and Ethnology, Harvard University, Cambridge, MA, 234 p.

Wright, K. 1991, The origins and development of ground stone assemblages in Late Pleistocene Southwest Asia. Paléorient, 17(1): 19-45. doi:10.3406/paleo.1991.4537

Wright, K. 1993, Early Holocene ground stone assemblages in the Levant. Levant, 25: 93111. doi:10.1179/lev.1993.25.1.93 
Wright, K. I. 1994, Ground-stone tools and hunter-gatherer subsistence in southwest Asia: Implications for the transition to farming. American Antiquity, 59(2): 238-263. doi:10.2307/281929

Wright, K. I. 2000, The social origins of cooking and dining in early village of Western Asia. Proceedings of the Prehistoric Society, 66: 89-121. doi:10.1017/S0079497X0000178X

Wright, K. I. 2014, Domestication and inequality? Household, corporate groups and food processing tools at Neolithic Çatalhöyük. Journal of Anthropological Archaeology, 33: 1-33. doi:10.1016/j.jaa.2013.09.007

Yohe II, R. M., Newman, M. E., \& Schneider, J. S. 1991, Immunological identification of small-mammal proteins on aboriginal milling equipment. American Antiquity, 56(4): 659-666. doi:10.2307/281543 